\title{
Organizational-and-technological solutions for waterproofing joints of highly prefabricated coating panels
}

\author{
Boris Zhadanovsky*, Sergey Sinenko, Anastasia Slavina \\ Moscow State University of Civil Engineering, 129377, Moscow, Russia
}

\begin{abstract}
This paper describes the technology and organization of the production of works on waterproofing the joints of highly prefabricated coating panels on a soft roof. The process of manufacturing waterproofing works can be divided into three stages - preparatory, main and final ones. Each stage has its own technological features and rules for performing work. The quality of execution of each stage affects the quality of work as a whole, ultimately providing the necessary reliability and strength of the coating.
\end{abstract}

\section{Introduction}

The coating panel is an element of the system that performs a load-bearing function. In the process of manufacturing a prefabricated coating panel, it is necessary to provide thermal insulation by gluing waterproofing layers. Despite the fact that the rolled carpet can be glued without thermal insulation, the panel manufacturing technology remains the same as with the installation of thermal insulation layers. The waterproofing layers are glued to each other and to the surface layer of concrete of the covering panel in various ways. It must be remembered that the roof covering is the most important part of the building, and the quality of operation of the building or structure will also depend on the quality of the roofing work [1-13].

\section{Materials and Methods}

When carrying out work on the organization of waterproofing the joints of the panels, it is advisable to consider the following issues: how will the preparation of the organization of workplaces be carried out, on what areas will the initial materials be placed, taking into account the preservation of their quality over time, the place of storage of the inventory, how will the safety be ensured during the work and etc.

The preparatory stage of waterproofing joints can include the organization of storage sites, cost planning, the formation of a work plan, the division of the scope of work, taking into account the available labor resources, advanced training of engineers, technicians and workers, the acquisition and transportation of the necessary materials and mechanisms.

${ }^{*}$ Corresponding author: JadanovskiyBV@mgsu.ru 
At the main stage, the organization and technology of processes for waterproofing the joints ofhighly prefabricated coating panels is carried out. The work includes pasting the joints with two strips of roofing felt by plasticizing the mastic layers of the glued roll waterproofing materials with a solvent.

Before starting work on gluing joints, the following technological operations must be performed:

- cover panels are installed and fixed;

- joints are filled with cement-sand mortar;

- mounting hinges on panels are cut off;

- acts for hidden works are drawn up.

For pasting joints, for example, the RM-420-1.0 or RM-500-2.0 fused roofing felt should be used according to the Russian State Standard TU 21-27-35-78.

To liquefy the mastic layer of the fused roofing felt, it is possible to use one of the following solvents:

- gasoline-solvent in accordance with GOST 3134-78;

- TS-1 fuel in accordance with GOST 10227-62;

- lamp kerosene in accordance with GOST 4753-68;

- kerosene for technical purposes in accordance with GOST 1899-73.

With the help of solvents, the roofing felt application is allowed at an ambient temperature of at least $+5^{\circ} \mathrm{C}$.

The joints between the panels should be peeled off in the direction from low to high places, i.e., for example, from the chute to the parapets.

After the cement-sand mortar of the joints has hardened, but not earlier than 24 hours later, the joints are glued together with two strips of roofing felt (Fig. 1,2,3,4). Pasting places must be pre-cleaned of debris and dust, and in the presence of excess moisture dried.

Technological operations for pasting joints, as well as technical requirements for pasting and the necessary mechanisms and devices are shown in Table 1.

Pasting of joints is performed by a link of two roofers of the 4th category and one roofer of the 3rd category. This is a manual operation that can be mechanized with a Karcher type washer or a Russian-made washer.

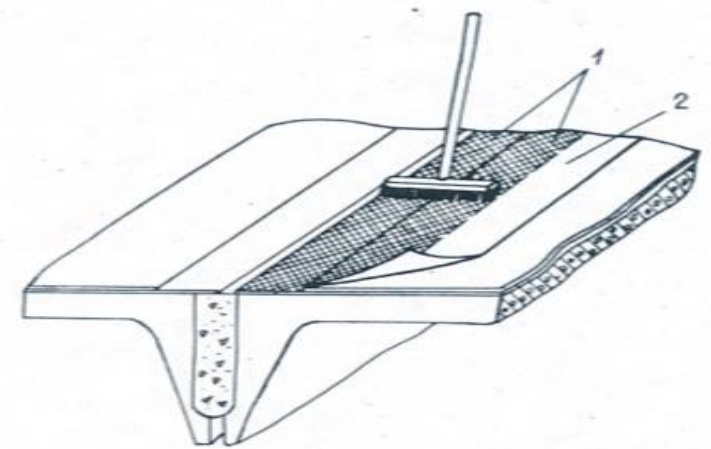

Fig. 1. Scheme of wetting the first strip of roofing felt with a solvent: $1-$ strips of roofing felt and bases wetted with solvent; 2 - a roll of roofing felt $220 \mathrm{~mm}$ wide.

Table 1. Technical requirements for pasting joints, a list of mechanisms and devices

\begin{tabular}{|l|l|l|l|l|}
\hline $\begin{array}{l}\text { Technological } \\
\text { operations }\end{array}$ & Scope of work & $\begin{array}{l}\text { Mechanisms, } \\
\text { fixtures and } \\
\text { tools }\end{array}$ & $\begin{array}{l}\text { Technical } \\
\text { requirements }\end{array}$ & $\begin{array}{l}\text { Link } \\
\text { composition }\end{array}$ \\
\hline $\begin{array}{l}\text { Surface } \\
\text { preparation of }\end{array}$ & $\begin{array}{l}\text { To clear the rolls of } \\
\text { roofing felt from the }\end{array}$ & $\begin{array}{l}\text { SO-98machine } \\
\text { for rereeling and }\end{array}$ & $\begin{array}{l}\text { Roofing felt, in } \\
\text { order to avoid }\end{array}$ & $\begin{array}{l}\text { Roofers } \\
4 \text { category- }\end{array}$ \\
\hline
\end{tabular}




\begin{tabular}{|c|c|c|c|c|}
\hline $\begin{array}{l}\text { materials to } \\
\text { be bonded }\end{array}$ & $\begin{array}{l}\text { sprinkling, unroll and } \\
\text { keep in an unrolled } \\
\text { form until the } \\
\text { waviness disappears } \\
\text { completely. Unroll } \\
\text { and hold in a } \\
\text { procurement and } \\
\text { storage room. }\end{array}$ & $\begin{array}{ll}\text { cleaning roll } \\
\text { materials }\end{array}$ & $\begin{array}{l}\text { cracking of the } \\
\text { mastic layer, } \\
\text { must be kept for } \\
24 \text { hours at a } \\
\text { temperature not } \\
\text { lower than } \\
+12^{0} \mathrm{C} \text {. }\end{array}$ & $\begin{array}{ll}1 & \\
3 & \text { category- } \\
1 & \end{array}$ \\
\hline $\begin{array}{l}\text { Cutting of the } \\
\text { roofing felt }\end{array}$ & $\begin{array}{l}\text { Using a metal ruler, } \\
\text { tape measure and } \\
\text { chalk, mark the } \\
\text { unrolled rolls for } \\
\text { panels } 220 \text { and } 420 \\
\text { mm wide. Cut along } \\
\text { the markings and roll } \\
\text { the work pieces into } \\
\text { rolls. Roofing felt } \\
\text { strips must be } \\
\text { prepared for the entire } \\
\text { object. It is necessary } \\
\text { to cut and store the cut } \\
\text { roofing felt in the } \\
\text { procurement } \\
\text { storage room. and }\end{array}$ & $\begin{array}{l}\text { Metal ruler, tape } \\
\text { measure, chalk, } \\
\text { roofing knife }\end{array}$ & $\begin{array}{l}\text { Straightness of } \\
\text { cutting. Work } \\
\text { pieces with a } \\
\text { width of } 220 \\
\text { mm are rolled } \\
\text { with a thickened } \\
\text { mastic layer } \\
\text { inward, and } 420 \\
\text { mm wide - with } \\
\text { a thickened } \\
\text { mastic layer } \\
\text { outward. }\end{array}$ & $\begin{array}{ll}\text { Roofers } \\
4 & \text { category- } \\
1 & \\
3 & \text { category- } \\
1 & \end{array}$ \\
\hline $\begin{array}{l}\text { Preparation of } \\
\text { joints for } \\
\text { pasting with } \\
\text { strips of } \\
\text { roofing felt }\end{array}$ & $\begin{array}{l}\text { For pasting with } \\
\text { roofing material, the } \\
\text { joints must be cleaned } \\
\text { of debris and dust, and } \\
\text { in the presence of } \\
\text { moisture - dried }\end{array}$ & $\begin{array}{l}\text { Brooms, } \\
\text { brushes }\end{array}$ & - & $\begin{array}{l}\text { Roofer } \\
3 \text { category- } \\
1\end{array}$ \\
\hline $\begin{array}{l}\text { Bonding the } \\
\text { first strip of } \\
\text { roofing felt } \\
220 \mathrm{~mm} \text { wide }\end{array}$ & $\begin{array}{l}\text { A roll of roofing felt } \\
220 \text { mm wide is rolled } \\
\text { out next to the place } \\
\text { of gluing (end-to-end) } \\
\text { with a thickened } \\
\text { mastic layer upwards. } \\
\text { Using a brush or a } \\
\text { roller, the solvent is } \\
\text { simultaneously } \\
\text { applied to the gluing } \\
\text { strip lprotruding } \\
\text { bottom layer of } \\
\text { waterproofing of the } \\
\text { panel } 100 \text { mm wide) } \\
\text { and to the unrolled } \\
\text { roll to a width of } 100 \\
\text { mm. Then the roll is } \\
\text { turned over, laid with } \\
\text { a softened surface, } \\
\text { straightened and } \\
\text { stretched. After } 7-10 \\
\text { minutes, the laid roll } \\
\text { is rubbed with a rake. } \\
\text { If the strip of glued } \\
\text { roofing felt consists of } \\
2 \text { pieces, the overlap } \\
\text { of one piece on the }\end{array}$ & $\begin{array}{lr}\text { Bucket } & \text { of } \\
\text { solvent, brush, } \\
\text { roller } \\
\text { Karcher }\end{array}$ & $\begin{array}{l}\text { The glued strip } \\
\text { must be located } \\
\text { in the gap } \\
\text { formed by the } \\
\text { upper layers of } \\
\text { roofing felt of } \\
\text { the panels to be } \\
\text { joined. } \\
\text { amount The } \\
\text { solvent applied } \\
\text { to each bonded } \\
\text { surface should } \\
\text { be } 0.045-0.065 \\
\text { kg/m }{ }^{2} \text { The } \\
\text { normal amount } \\
\text { of the applied } \\
\text { solvent is } \\
\text { determined } \\
\text { visually by the } \\
\text { continuity of } \\
\text { wetting and the } \\
\text { absence } \\
\text { smudges of }\end{array}$ & $\begin{array}{l}\text { Roofers } \\
4 \text { category- } \\
2\end{array}$ \\
\hline
\end{tabular}


Bonding the second strip $420 \mathrm{~mm}$ wide other should be 100
$\mathrm{~mm}$.
The roofer places a
roll of roofing felt at
the beginning of the
gluing strip, rolls
out by $1.5 \mathrm{~m}$ in the
direction of the pasting and bends the free end by $0.5 \mathrm{~m}$. The second roofer, using a gun, moistens the bent end of the roll $(0.5 \mathrm{~m})$ and a part of the base on which the wetted part of the roll will be glued with solvent. The bent end is straightened, laid in place and rubbed in with a rake.

The roll is rolled back. Then one roofer pushes the roll with a rake and rolls it out, and the second roofer Electrospray gun, rake, SO108 device uses a gun to wet the roll and the base at the same time. After 7-15 minutes, the laid roll should be rolled twice with a roller. Particular attention is paid to the gluing of the edges.

If the strip of glued roofing felt consists of 2 pieces, the overlap of one piece on the other should be 100 $\mathrm{mm}$, and the overlaps of the upper and lower strips should be displaced relative to each other by at least $300 \mathrm{~mm}$.
The strip of roofing felt should be located symmetrically to the geometric dimensions of the panel joint. The pasting of the roll should be continuous, without swelling and non-pasting. The amount of solvent applied to each bonded surface should be $0.045-0.065$ $\mathrm{kg} / \mathrm{m}^{2}$.

The normal amount of the applied solvent is determined visually by the continuity of wetting and the absence of smudges
Roofers

4 category2 


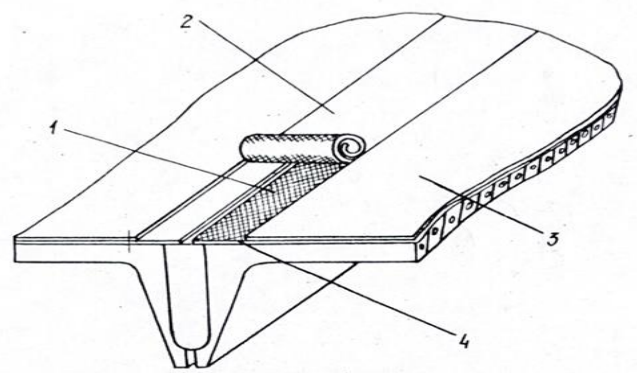

Fig. 2. Pasting of the first strip of roofing felt: 1 - the place of gluing the first strip of roofing felt (along the entire length of the panel); 2 - the first strip of roofing felt $220 \mathrm{~mm}$ wide, glued on one side along the entire length of the panel; 3 - second layer of waterproofing panel; 4 - first layer of waterproofing panel

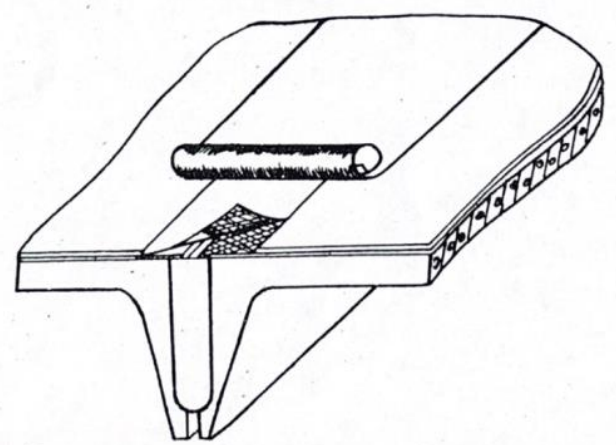

Fig. 3. Pasting of the second strip of roofing felt $420 \mathrm{~mm}$ wide, glued to the panels

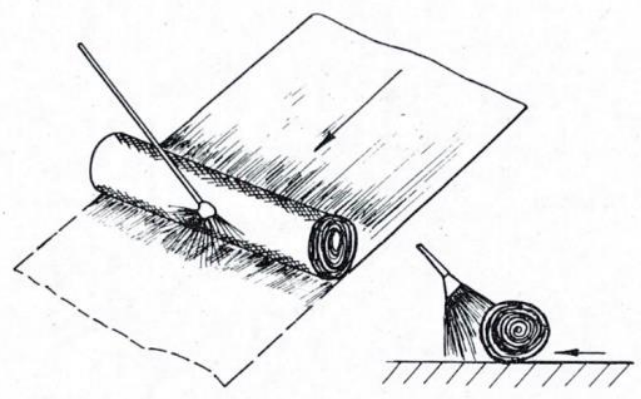

Fig. 4. Diagram of the correct position of the solvent spray when gluing roofing felt

The calculation of labor costs for waterproofing a $100 \mathrm{~m}$ joint is presented in Table 2.

Table 2. Calculation of labor costs for waterproofing $100 \mathrm{~m}$ joint

\begin{tabular}{|c|c|c|c|c|c|c|c|}
\hline Justification & $\begin{array}{l}\text { Name of } \\
\text { works }\end{array}$ & $\begin{array}{l}\text { Unit of } \\
\text { measurement }\end{array}$ & $\begin{array}{l}\text { Scope } \\
\text { of } \\
\text { work }\end{array}$ & $\begin{array}{l}\text { Rate } \\
\text { of } \\
\text { time } \\
\text { per } \\
\text { unit }\end{array}$ & $\begin{array}{l}\text { Labor } \\
\text { costs } \\
\text { for the } \\
\text { total } \\
\text { volume }\end{array}$ & $\begin{array}{l}\text { Price } \\
\text { per } \\
\text { unit } \\
\text { of } \\
\text { meas., }\end{array}$ & $\begin{array}{l}\text { Salary } \\
\text { for the } \\
\text { total } \\
\text { amount } \\
\text { of work, }\end{array}$ \\
\hline
\end{tabular}




\begin{tabular}{|c|c|c|c|c|c|c|c|}
\hline & & & & $\begin{array}{l}\text { of } \\
\text { meas., } \\
\text { man-h }\end{array}$ & $\begin{array}{l}\text { of } \\
\text { work, } \\
\text { man-h }\end{array}$ & $\begin{array}{l}\text { Rub- } \\
\text { kop. }\end{array}$ & Rub-kop \\
\hline \multicolumn{8}{|c|}{ MAIN WORKS } \\
\hline $\begin{array}{l}\text { Calculation } \\
\text { No. } 1\end{array}$ & $\begin{array}{l}\begin{array}{l}\text { Laying } \\
\text { of }\end{array} \text { rtrips } \\
\text { material, } \\
\text { cutting strips } \\
\text { and gluing } \\
\text { them by } \\
\text { liquefying the } \\
\text { mastic layer } \\
\text { of fused } \\
\text { roofing felts } \\
\text { using solvents }\end{array}$ & $100 \mathrm{~m}$ joint & 1.0 & 3.03 & 3.03 & $\begin{array}{l}1- \\
64.1\end{array}$ & $1-64.1$ \\
\hline \multicolumn{8}{|c|}{ TRANSPORTATION AND AUXILIARY WORKS } \\
\hline $\begin{array}{l}\text { Unified } \\
\text { Norms and } \\
\text { Prices 1979 } \\
\$ 1-11.3-3\end{array}$ & $\begin{array}{l}\text { Unloading roll } \\
\text { materials from } \\
\text { a car and } \\
\text { stacking them }\end{array}$ & $1 \mathrm{t}$ & 0.2 & 0.57 & 0.114 & $0-25$ & $0-0.5$ \\
\hline $\begin{array}{l}\text { Unified } \\
\text { Norms and } \\
\text { Prices } 1979 \\
\S 1-15, \text { No.8 }\end{array}$ & $\begin{array}{l}\text { Stacking roll } \\
\text { materials in } \\
\text { container bags } \\
\text { for lifting }\end{array}$ & $1 \mathrm{t}$ & 0.2 & 0.98 & 0.196 & $\begin{array}{l}0- \\
42.9\end{array}$ & $0-08.6$ \\
\hline $\begin{array}{l}\text { Unified } \\
\text { Norms and } \\
\text { Prices } 1979 \\
\S 1-13, \text { No.8 }\end{array}$ & $\begin{array}{lr}\text { Carry } & \text { rolls } \\
\text { and } & \text { solvent } \\
\text { over } & \text { the } \\
\text { coating up to } \\
50 \mathrm{~m}\end{array}$ & $1 \mathrm{t}$ & 0.2 & 0.21 & 1.45 & $\begin{array}{l}0- \\
93.6\end{array}$ & $0-19.6$ \\
\hline Total & & & & 0.760 & & $\begin{array}{l}0- \\
33.2\end{array}$ & \\
\hline \multicolumn{8}{|c|}{ VERTICAL TRANSPORTATION OF MATERIALS } \\
\hline $\begin{array}{l}\text { Unified } \\
\text { Norms and } \\
\text { Prices } 1979 \\
\S 1-8, \S 21\end{array}$ & $\begin{array}{l}\text { Transportation } \\
\text { of materials } \\
\text { by a Pioneer } \\
\text { crane and T- } \\
108 \text { to a } \\
\text { height of } 20 \mathrm{~m} \\
\text { with slinging } \\
\text { and racking: } \\
\text { For drivers } \\
\text { For a rigger }\end{array}$ & & & & & & \\
\hline
\end{tabular}

Examples of calculating the amount of work, consumables and resources are given below. Calculation No. 1. Pasting of 2 layers of roofing felt by breaking up the mastic layer with a solvent (per $100 \mathrm{~m}$ of the joint) is presented in Table 3.

Table 3. Examples of calculating the amount of work, consumables and resources

\begin{tabular}{|l|l|}
\hline $\begin{array}{l}\text { Unified Norms and Prices, §7-1, } \\
\text { No.15 }\end{array}$ & $\begin{array}{l}\text { Cleaning joints from debris per } 100 \mathrm{~m} \text { of a joint } 0.5 \mathrm{~m} \\
\text { wide } \\
\frac{0.5}{0.5} \times \frac{1.05}{0-51.8}=\frac{0.52}{0-25.9} \frac{\mathrm{man}-\mathrm{h}}{\mathrm{Rub}-\mathrm{kop} .}\end{array}$ \\
\hline Unified Norms and Prices, §11-66 & $\begin{array}{l}\text { Cleaning of roll materials per } 100 \mathrm{~m} \text { joint } \\
\\
\end{array} \frac{0.74}{0.74} \times \frac{0.6}{0-31.4}=\frac{0.44}{0-23.2} \frac{\mathrm{man}-\mathrm{h}}{\mathrm{Rub}-\mathrm{kop} .}$ \\
\hline
\end{tabular}




\begin{tabular}{|c|c|}
\hline $\begin{array}{l}\text { Calculation of economic efficiency } \\
2489.00 .000, \quad \text { TsEKB } \\
\text { StroymehavtomatikaTsNIIOMTP }\end{array}$ & $\begin{array}{l}\text { Bonding the 1st strip of roofing felt } 0.22 \mathrm{~m} \text { wide on } 100 \\
\mathrm{~m} \text { of the joint } \\
\frac{0.25}{0.25} \times \frac{2.83}{1-57.6}=\frac{0.71}{0-39.4} \frac{\mathrm{man}-\mathrm{h}}{\mathrm{Rub}-\mathrm{kon}}\end{array}$ \\
\hline $\begin{array}{l}\text { TsEKB } \\
\text { StroymehavtomatikaTsNIIOMTP }\end{array}$ & $\begin{array}{l}\text { Bonding 2-01 strips of roofing felt } 0.42 \mathrm{~m} \text { wide on } 100 \mathrm{~m} \\
\frac{0.48}{0.48} \times \frac{2.83}{1-57.6}=\frac{1.36}{0-75.6} \frac{\mathrm{man}-\mathrm{h}}{\mathrm{Rub}-\mathrm{kop} .}\end{array}$ \\
\hline$\frac{0.52+0.44}{.9+0-23.2}$ & $\frac{0.71+1.36}{0-39.4+0-75.6}=\frac{3.03}{1-64.1} \frac{\mathrm{man}-\mathrm{h}}{\mathrm{Rub}-\mathrm{kop} .}$ \\
\hline
\end{tabular}

The need for basic materials and semi-finished products is shown in table 4 .

Table 4. Material and technical resources

\begin{tabular}{|l|l|l|l|}
\hline Name & Grade & $\begin{array}{l}\text { Unit of } \\
\text { measurement }\end{array}$ & $\begin{array}{l}\text { Quantity per } 100 \mathrm{~m} \text { of } \\
\text { joint }\end{array}$ \\
\hline $\begin{array}{l}\text { Roofing felt } \\
\text { (K-1.15) }\end{array}$ & RM 500-2.0 or RM-420-2.0 & $\mathrm{m}^{2}$ & 73 \\
\hline $\begin{array}{l}\text { Solvent } \\
\text { (one of the } \\
\text { listed) }\end{array}$ & $\begin{array}{l}\text { Gasoline-solvent } \\
\text { TS-1 fuel } \\
\text { Lamp kerosene } \\
\text { Kerosene for technical purposes }\end{array}$ & $\mathrm{t}$ & 0.01 \\
\hline
\end{tabular}

The need for machines and mechanisms is shown in table 5.

Table 5. The need for machines and mechanisms

\begin{tabular}{|l|c|}
\hline Name & Quantity \\
\hline Electrospray gun for solvent application & 1 \\
Solvent cans & 2 \\
Rake OTU 22-475-66 & 2 \\
Rolling device SO-108 & 1 \\
Crane "Pioneer" & 1 \\
Roofing knife & 1 \\
Roulette RZ-420 in accordance with GOST 7502-69 & 1 \\
Metal ruler 500 mm long in accordance with GOST 427-75 & 1 \\
Solvent bucket & 2 \\
Brush or roller & 2 \\
\hline
\end{tabular}

\section{Results}

An important part and a condition for carrying out work is to ensure the necessary labor safety, as well as compliance with fire and environmental safety rules.

Workers may be allowed to work on the roof only if they undergo an appropriate medical examination. Persons with skin diseases, upper respiratory tract diseases should not be allowed to work with hot materials. Also, persons under the age of 18 and pregnant women are not allowed.

Workers should be provided with appropriate work clothing, special footwear and personal protective equipment. Primarily, each roofer must undergo safety instructions for performing technological operations, which must be marked in the relevant documents.

Before starting work on the roof, it is necessary to check the surface for the serviceability of the supporting base. It is forbidden to work on the roof without insurance. In the case of work on the edge of the roof that does not have a fence, the worker must be provided with a safety belt. 
The area where materials can fall must be fenced. In case of unfavorable weather conditions (fog, ice, heavy rain or snow), roofing work is prohibited.

When installing roll roofs made of fused roofing felt using a solvent, the requirements of GOST "Labor safety in construction", part 1, part 2; "Fire safety rules for welding and other hot work at national economy facilities"; "Fire safety rules during construction and installation works" should be met.

Roofing work sites must be fenced and have safety signs in accordance with current regulatory documents.

The equipment used for the installation of roll roofing must meet safety requirements in accordance with GOST 12.2.003-74.

When working with mechanisms, it is necessary to follow the safety rules attached to the operating instructions for these mechanisms.

Ladders, access boards, bridges and other devices must meet the requirements of GOST 12.2.012-75.

During the period of roofing work, the following fire-fighting stands and first aid equipment should be on the site of one link:

- box with sand $0.5 \mathrm{~m}^{3}-1 \mathrm{pc}$.

- bucket

- shovels - 2 pes.

- foam fire extinguishers -4 pcs.

- hook - 1 pc.

- ax

- first aid kit with a set of medicines - 1 pc.

Unauthorized persons are prohibited from staying in the working area during roofing work. There must be at least one emergency exit from the roof of the building where roofing works are carried out.

A changeable amount of solvent should be placed at a distance of at least $20 \mathrm{~m}$ from the work area in a place that has safety signs and is protected from direct sunlight.

When performing roofing work with a solvent, personal protective equipment must be used:

- clothes of the $\mathrm{N}_{\mathrm{t}}$ subgroup in accordance with GOST 12.4.015-76,

- special gloves of type E in accordance with GOST 12.4.010-75,

- leather footwear of group 0 in accordance with GOST 12.4.017-76,

- respirators RPG-67A in accordance with GOST 12.4.004-74,

- respirators RU-60 with cartridge A in accordance with GOST 17269-71.

"No smoking" posters should be displayed in the work area.

To remove bitumen from skin, it is necessary to use certified pastes. Do not use solvents for cleaning the skin that can cause irritation or skin disease.

Also, it is necessary to take into account the peculiarities of the production of work not only in the summer, but also in the winter. For the organization of work, a temperature of at least minus $20^{\circ} \mathrm{C}$ is suitable. Regardless of the weather conditions, all materials must be warm before laying, i.e. they must be in a warm room or be warmed up to a positive temperature and delivered to the place of laying in an insulated container. Before carrying out work on the roof, the surface must be cleared of debris, frost, snow and ice.

\section{Conclusions}

The organization and technology of the production of works on waterproofing the joints of highly prefabricated coating panels, subject to the requirements developed by main design solutions, allows performing high-quality work with the required safety. 


\section{References}

1. P.P. Oleynik, Organization of construction production (Moscow, ASV Publishing House, 2010).

2. S.A. Sinenko, Foundations of the regulatory framework in construction (Moscow, ASV Publishing House, 2015).

3. V.V. Kucherzhenko, V.M. Lebedev, Texnologiya I rekonstrukciya zdanij I sooruzhenij (Moscow, Izdatel'stvo ASV, 2007).

4. B.F. Shirshikov, M.N. Ershov, Rekonstrukciyaob“ektov. Organizaciya rabot. Ogranicheniya. Riski (Moscow, Izdatel`stvo ASV, 2010).

5. M.V. Berlinov, Osnovaniya I fundamenty (Moscow, Izdatel`stvo Lan', 2011).

6. S.A. Sinenko et al., Osnovy 'normativnoj bazy`v stroitel’stve (Moscow, Izdatel`stvo ASV, 2016).

7. B.F. Shirshikov et al., Organizacionno-texnologicheskie resheniya po bezopasnosti truda v proektax proizvodstva rabot (Moscow, Izdatel'stvo ASV, 2015)

8. M.N. Ershov et al., Proizvodstvo krovel 'ny`x rabot I ustrojstvo zashhitny ‘xpokry`tij (Moscow, Izdatel'stvo ASV, 2016)

9. P.P. Olejnik, B.F. Shirshikov, Sostav razdelov organizacionno-texnologicheskoj dokumentacii I trebovaniya k ix soderzhaniyu (Moscow, Izdatel`stvo MGSU, 2013)

10. B.F. Olejnik, V.I. Brodskij, Organizaciya stroitel'nogo proizvodstva. Podgotovka I proizvodstvo stroitel 'no-montazhny’x rabot (Moscow, Izdatel’stvo MGSU, 2014)

11. S. Sinenkoet al., IOP Conference Series: Materials Science and Engineering $\mathbf{7 5 3}$ 042012 (2020). doi:10.1088/1757-899X/753/4/042012

12. O. Salosin, IOP Publishing $1614012028 \quad$ (2020). doi:10.1088/1742$6596 / 1614 / 1 / 012028$

13. L. A. Demidova et al., Prinyatie reshenij v usloviyax neopredelennosti (Moscow, Goryachayaliniya, Telekom, 2015). 